\title{
LEGAL ACTIONS FOR MINOR OFFENDERS IN COLOMBIA
}

\author{
Lorena Elizabeth CABRERA IZQUIERDO, PhD \\ University of Seville, Spain \\ Faculty of Legal Sciences, Universidad del Atlántico \\ Barranquilla/Colombia
}

\begin{abstract}
Minors are responsible facing the law, and therefore are subject to all laws previously established; provided that there's a crime stated in the criminal code or special penal laws, and that they're found guilty. However, unlike the actions in the criminal code for adults (Boldov 2002, 1554), the criminal law for minors requires talking about a diminished guilt, taking into account the lower degree of psychological development found in minors (Aguado and Gonzáles 2002, 6566).

The choice of the right legal measure is done in a flexible way, not only to legal proof and assessment, but also considering age, family and social circumstances, character and interests of the minor (Martín 2008, 42) (Martín 2001, 70).
\end{abstract}

\section{Keywords}

Measures; minors; Latin America.

\section{COMMON TERMS}

International legislation establishes the obligation of counting on a range of options as an answer when declaring the responsibilities of an adolescent person as the author of an offense. About this judgment, most legal systems in Latin America (Berrios 2011, 163-191) and Spain (Organic Law 2000, 5), establish 
several sanctions, leaving the judge with the option of imposing on the adolescent offender one or many of them, in a simultaneous, consecutive or alternate way.

It is necessary to point out that the Convention on the Rights of the Child (UNCRC, 1989, Art. 37) and the Beijing rules both make a common cause, they protect the basic right to freedom and exceptionality of imposing sanctions that deprive the personal liberty of a minor person, reserving such sanction only as a last resource for serious acts and unless there is no other appropriate response (United Nations General Assembly 1985, R -17, 17.2, 17.3, 19, 19.1).

The implementation of the system of sanctions and measures is based on a pedagogical model (Rodríguez 2004, 169-183), which formally meets the social needs of each individual and tends to provide the lowest offender with training based on values and recognition of their rights. (Muñoz 2001, 189 - 190) and their obligations as citizens, with full compliance with all procedural guarantees. Article 140 of Law 1098 of 2006 for the Colombian case establishes the purpose of the system of criminal responsibility for adolescents, indicating that the measures taken are pedagogical, specific and differentiated regarding the adult system, guaranteeing restorative justice.

Through the restorative pedagogical model created under the guidelines of the SCRA (System of criminal responsibilities for adolescents), there is the intention of resocialization and rehabilitation of adolescent offenders, through the creation of spaces for reflection that lead young people to propose positive changes in their life projects, the recognition of the consequences of the commission of the punishable act; seeking to that extent to generate in juvenile offenders sufficient motivation to reach the stage of repairing the damage and reduce the chances of recidivism (Forero et al. 2010, 6-7).

Such actions as the approach of the victim, victimizer and society play a key role in promoting in the young person an attitude aimed at repairing the harm and a negative attitude with respect to the possibilities of re-offending. 


\section{PRECAUTIONARY MEASURES}

\subsection{Personal precautionary measures}

An approach to the concept of personal precautionary measures allows their definition as those that are adopted in a manner motivated by a jurisdictional body with a double objective, firstly to ensure the future execution of a possible conviction, and at the same time, to neutralize the harmful consequences that may result in the possible escape of the alleged offender, in his or her recidivism (García-Rostán 2007,105) and in the destruction or concealment of evidence (Valbuena 2008, 62).

The function of the precautionary measure is to preserve the effectiveness of the process (Portal 2008, 50), considering effectiveness as the possibility that the content of the final resolution can be complied with on its completion (Portal 2008, 123).

The precautionary measures in the process of minors correspond to characteristics of jurisdiction, temporariness, variability and education (Chocrón 2008, 250-251) and must be adopted with respect and application as a minimum of the guarantees and rights provided for adults, and with the specialties inherent to the age of the subjects for whom they are intended (Sanz 2007, 267268).

The personal precautionary measures are used to establish the parameters, criteria and guidelines in cases in which the preventive detention of a minor offender is appropriate. In addition, the stipulations of article 17 of the United Nations Rules for the Protection of Juveniles Deprived of their Liberty (United Nations General Assembly 1985, 17) should also be considered.

Consequently, the so-called preventive detention can only be declared as a precautionary or prior measure under the assumptions foreseen in the norm, that is, the risk of the minor evading the process, the obstruction of evidence and the serious danger for the victim, the complainant, the witness or the community. In such a way, the measure must respond to purposes admitted by the superior order in favour of the correct administration of justice and the benefit of society (Espitía 2003, 291), that is to say, that it responds to the social 
need to avoid risks for the correct development of the process or for the execution of the sanction (Pabón 2007, 383).

There are other types of risks that have been excluded, because they are not considered as dangerous situations that create the conditions for criminal repetition. So, for example, the situation of helplessness of the minor or the social environment in which he or she is being held cannot be taken as an excuse for precautionary detention, although in many cases these lacks are directly related to the crime (Pabón 2007, 384).

It can also be deduced from the prescription in paragraph 1 of article 181 that it must be applied in accordance with the criteria established in article 187 in the case of measures of deprivation of liberty, a point on which we will refer in detail below.

\section{DEFINITIVE MEASURES}

Any approach to the way in which the law addresses the legal consequences linked to the commission of a criminal act must take into account that the regime of measures represents one of the most striking indicators of the way in which the legislator deals with the responsibility of the young offender.

The law, when contemplating a catalogue of measures, condenses the limits up to which the legislator is willing to treat the minor with a different scale than the adult delinquent (Gómez 2001, 282).

The definitive measures that must be imposed on the adolescent who has violated the criminal law must respond mainly to the principle of flexibility (Pabón 2007, 360), as the penalty not only constitutes a punishment or a way of blaming the minor for what he or she did, but also becomes a mechanism for his or her education and training (United Nations General Assembly 1989, 40.4). The measures applicable to the minor offender that are mostly accepted in Latin America are:

- Admonishment

- Imposition of rules of conduct.

- Community service. 
- Assisted liberty.

- Confinement in a semi-closed environment.

- Deprivation of liberty in a specialized care center.

\subsection{Aspects common to all measures}

\subsubsection{Target group}

About the recipients of the measures, three groups are distinguished, with regard to the possibilities of application of the measures.

The first, between the ages of fourteen and sixteen, may be subject to any of the measures from the Code of Childhood and Adolescence, except for deprivation of liberty.

The second, between the ages of sixteen and eighteen, to whom deprivation of liberty in a specialized institution shall apply if they are found responsible for the commission of crimes whose minimum penalty established in the penal code is or exceeds six years of imprisonment.

The third, for adolescents over fourteen years of age and under eighteen years of age, who are found responsible for intentional homicide, kidnapping, extortion in all its forms and aggravated crimes against freedom, integrity and sexual formation.

\subsubsection{Discretion of the judge in the choice of legal consequences}

The person in charge of the imposition and control of the measures is the trial judge, who, with the selection and application of a measure (Cuello 2000, 61-62), must pursue the aims of the law, that is, to be protective, educational and restorative. 


\subsubsection{Duration of measures and judicial quantification}

Given the principle of flexibility and discretion inherent in the system, the law only sets the maximum and minimum time limits for each of the measures, leaving a wide margin of action to the judge for the purposes of quantification.

\subsubsection{Jurisdiction to implement measures}

The Colombian Family Welfare Institute and the other institutions that form part of the National Family Welfare System have administrative competence common to all measure, such as Municipalities and Departments and the judge who issued the sanction is competent to control the execution.

\subsection{Cautions}

In terms of the Code of Childhood and Adolescence, it is the recrimination (Álvarez 2007, 188) that the judicial authority makes to the adolescents about the consequences of the criminal act and the demand for reparation of the damage. In all cases, they must attend an educational course on respect for human rights and citizen coexistence, which will be run by the Institute of Studies of the Public Prosecutor's Office (Instituto de Estudios del Ministerio Público).

In the event of a conviction for damages, the judicial officer shall order the minor and his or her parents to pay the damages in accordance with the terms of the sentence.

The juvenile court judge, in the application of the reprimand measure, considered to be a light measure (Tejedor 2001, 250), must be guided by pedagogical rather than paternalistic criteria, in order to make the juvenile offender understand the harmful nature of his or her behaviour for society, always using language that is understandable and appropriate to his or her age. The effectiveness of the measure will depend in part on the receptivity of the 
minor, but the capacity, training and specialization in this matter of the judge also plays an important role (Hava 2004,172).

\subsection{Implementing rules of conduct}

Article 183 of the Colombian Code of Childhood and Adolescence establishes that the judicial authority imposes obligations or prohibitions on adolescents in order to regulate their way of life, as well as to promote and ensure their education.

This imposition cannot in any way restrict aspects inherent in the personality or self-image that the young person has and projects. These obligations cannot be stigmatizing or totalitarian, so that the young person can make certain decisions about himself or herself autonomously. For example, it would not be feasible to require a young person to dress in a specific way or to wear some kind of badge to differentiate him or her from other adolescents or schoolmates. It would be more feasible to propose orienting rules, that guide their conduct to generate orderly and harmonious living conditions, then it would be possible to work with rules such as a time to return home, the obligation to attend formal and informal educational centers, attend cultural, sports, and artistic activities among others.

Imposed behavioural rules must not exceed two (2) years.

\subsection{Social service to the community}

It prescribes the statute for minors in Colombia. This measure corresponds to tasks of general interest that the adolescent must perform, free of charge, for a period not exceeding six months, during a maximum of eight hours per week, preferably on weekends and public holidays or on working days but without affecting his or her school day.

The imposition of this measure implies that the adolescent must carry out unpaid activities, assumed according to his will, of social interest or executed for 
the benefit of people who are in a situation of vulnerability or weakness. The aim of this is for the minor to understand that the community has suffered the negative consequences of his actions and that for this reason he is susceptible to reproach and social control, for this reason the provision of services to the community is a good mechanism for repairing the damage (Landrove 2001, 81). The measure of providing services for the benefit of the community allows the cooperation of the minor in activities for the well-being of the community, through which it is intended to hold him/her responsible for his/her actions and for the damages and prejudices he/she has caused, in a positive and useful way for society (Vizcarro 2001, 154).

This measure cannot be imposed without the consent of the adolescent (Martín $2008,41)$, since otherwise, one would be faced with a situation of forced labor, in which the possibility of the adolescent disposing of his or her time in a free and autonomous manner would be restricted (Pabón 2007, 390-391).

\subsection{Probation}

It is the granting of freedom by the judicial authority to the adolescent with the mandatory condition of undergoing the supervision, assistance and guidance of a specialized care program. This measure may not last more than two years (Vizcarro 2001, 154).

The substantial aspect of this measure lies in the submission of the adolescent offender to a follow-up control of it. This personalized control measure seeks to ensure compliance with the tasks of the activity project assigned in an intervention program, under institutional control or supervision. (Collado 2000, 498).

It is clear that, in this measure, the minor remains free, but subject to the control of a professional, who is in charge of his follow-up, warning that the action of the educator is done from a double perspective, on the one hand, static or relative to the question of control and on the other, dynamic or relative to the educational question (Cezón 2001,56-58). 
In Colombia, although it is true that it is a measure frequently used by judicial operators; in practice, the availability of budget for its effective compliance has led to its ineffectiveness.

\subsection{Semi-closed confinement}

This sanction consists of the attendance of the minor to a program of specialized attention, in a schedule different from his/her school schedule, the sanction may not be superior to 3 years. However, the Colombian Family Welfare Institute (ICBF) considers that a minimum of six months should be contemplated for this sanction, even if the law does not stipulate it, so that the process has a real impact on the adolescent (Forero et. al. 2010, 28).

Semi-closed internment does not express the obligation of residence in the institution (Pollarolo 2009, 12-13), but the wording does not exclude these possibilities either. The expression "to attend" seems to be understood as something less than residence, so the scope of the sanction is restricted, since it will not be possible to impose to the minor the duty to spend the night or to stay in the institution all weekend, it would only cover his attendance in certain daytime hours to the educational and formative activities that are programmed.

\subsection{Deprivation of liberty}

It can be defined as the placement of the adolescent in a specialized care facility, that is, it is a custodial sanction in an institutional setting in which the adolescent remains until the sanction ceases or is modified.

Despite the repressive and restrictive nature of this measure, it should be noted that its essential function is to provide the child with an educational treatment through the development of training, educational, work and leisure activities, which aims to create in the child all the basic skills that lead to a responsible behaviour in the community (Belinchón 2001, 164). 
This measure of internment implies the separation of the minor from his/her environment, in order to take care of him/her in a center destined for reeducation. The purpose of this measure is to provide the minor with the necessary elements for personal growth and to facilitate the process of social integration. (Vásquez et al 2007, 153-154).

In this sense, it should be stressed that the limitation of freedom is not an end in itself but must be aimed at developing an intervention of training, learning and treatment, which enhances the integral development of the personality of juvenile inmate offenders. (Vizcarro 2001, 153-154).

The United Nations Rules for the Protection of Juveniles Deprived of their Liberty states in its rules the rights and principles that shall apply to adolescents who have been sentenced to deprivation of liberty, with a humanizing tendency to comply with the sanction.

According to Article 187 of Law 1098 of 2006, the measure of deprivation of liberty may be applied in two cases:

a) Adolescents over the age of sixteen and under the age of eighteen who are found responsible for the commission of crimes whose minimum penalty established in the Penal Code is or exceeds (6) years of imprisonment.

b) In cases where adolescents over fourteen (14) and under eighteen (18) are found responsible for intentional homicide, kidnapping or extortion, in all its forms.

The measure of deprivation of liberty (Carmona 2002, 294) in a confined environment is the most rigorous measure contained in Law 1098 of 2006, therefore the guarantees for its imposition and execution are made stricter, bearing in mind that it consists of depriving the condemned of the freedom of movement and all other rights indissolubly linked to it. (Mapelli Caffarena 2008, 156).

In his or her reasoning for the imposition of the measure of deprivation of liberty, the juvenile judge must consider two aspects, a qualitative and a quantitative one. The first is understood based on the necessity and appropriateness of the measure and the second to proceed to a quantitative 
delimitation, so that the selected measure is appropriate to achieve the purposes for which it was imposed. (Trejo 2005, 143-145).

\subsubsection{Rights of minors in detention}

Minors who have been deprived of their liberty have rights that are provided for in international conventions (United Nations General Assembly 1985, r-13), as well as in national standards, the respect for these guarantees is a requirement for social reinsertion. This basic idea translates into a commitment on the part of institutions not to restrict the rights of children in boarding schools, but only to do what is strictly necessary to comply with the measure, without forgetting its aims. (Mapelli Caffarena 2004, 207).

In the light of article 37 of the Convention on the Rights of the Child and in observance of its general principles, the following aspects may be clarified with reference to deprivation of liberty.

a) The deprivation of liberty must obey a legitimate decision of the competent authorities.

b) The parents or guardians of the child deprived of liberty are recognized by the Convention as having the primary responsibility for the protection and care of children, as is obvious with the limits on respect for the rights of the child, his or her best interests and attention to the evolving capacities of the child.

c) The conditions to be offered by the internment centers, as it is a human being in process of development and greater vulnerability, must be specific for them. They must be separated from adults and they should have a physical environment and conditions adapted to the objective of rehabilitation.

d) Professionals involved in the decision making and implementation processes of internment must have competence and continuous training in the field.

e) The state is the principal guarantor in the observance and effective respect of the rights to be guaranteed to the minor deprived of liberty 
(Carmona 2013, 91-100), it points out as rights of minors in conditions of internment: respect for one's own personality, the right to life, the right to integrity and health, the right to education and training, the right to privacy and dignity, the set of civil rights and the right not to be uprooted, to health care, and contact with the outside world. (Mapelli Caffarena 2004, 208-214).

\section{REGIONAL CONTEXT OF LEGAL MEASURES}

As we have seen so far, legal measures for minors in Colombia have been developed with an international perspective, and therefore, highlighting what is happening in Latin America is pertinent for their understanding.

The process of transition and reform in Latin America in the area of childhood and adolescence is restructured under the principle of comprehensive protection, to recognize the child as a subject with full rights and to respond to the violations committed. The Beijing Rules, in the event of a transgression of criminal law, provide for prejudicial instances of conflict resolution and judicial review if necessary.

In the case of Brazil, the Statute of the Child and Adolescent was sanctioned by Law 8069 of 1990, which distinguishes it from the adult judicial system according to (Beloff 1998, 5). First, it deals with persons under eighteen years of age who perpetrate the conduct described as the antecedent of a sanction, whether they are crimes or offenses. Second, it is a completely different system from the adult criminal justice system as minors are criminally unimputable. Third, one of these differences is expressed in the "measures" or legal consequences of the conduct that violates the criminal law when done by a person under the age of eighteen.

The Brazilian judicial system classifies children up to twelve years of age as incomplete, and teenagers between twelve and eighteen years of age, are unimputable and the protective measures applicable to the offending act according to Article 101 by the competent authority are: 
- Referral to parents or guardians, by means of a declaration of responsibility.

- Temporary guidance, support and follow-up.

- Compulsory enrolment and attendance in an official establishment of basic education.

- Inclusion in an official or community aid program for the family, the child and the adolescent.

- Application for medical, psychological or psychiatric treatment, with hospital or outpatient treatment.

- Inclusion in an official or community program of aid, orientation and treatment for alcoholics and drug addicts.

- Shelter for young people.

- Placement in a foster family.

The following socio-educational measures may be applied to the adolescent offender:

- Caution.

- Obligation to repair the damage.

- Provision of community service.

- Assisted liberty.

- Assignment in a semi-freedom regime.

- Internment in an educational establishment and any of those provided for in article 101, sections I to IV.

In summary, this system in Latin America has served as a model for the rest of the countries and deprivation of liberty is an exceptional and alternative measure, where children and adolescents enjoy all the procedural guarantees facing the regulatory activity carried out by the government.

The Peruvian Statute follows the same line of the Brazilian juvenile system in relation to offenders to criminal law according to (Beloff 1998, 7) in the protection measures, the problem is considered identical, with the automatic referral of children to the protection system. However, the Code regulates the issue without having a discussion on responsibility or non-imputability. 
The Chilean Law on Adolescent Criminal Responsibility (Ley de Responsabilidad Penal Adolescente "LRPA") is one of the most recent judicial systems in Latin America, adjusted to the standards proposed by the Convention on the Rights of the Child (Convención sobre los Derechos del Niño "CDN"). With the entry into force of Law No. 20,084, promulgated on November 28,2005 , the system is limited to adolescents between 14 and 18 years of age. With respect to protective measures, it replaces the penalties provided for in the Criminal Code, article 6 of the LRPA provides for a classification; penalties for offences, penalties for misdemeanors and accessory penalties.

Criminal penalties

- Internment in closed regime with program of social reinsertion.

- Internment in semi-closed regime with program of social reinsertion.

- Special assisted liberty.

- Assisted liberty.

- Community service provision.

- Repair of the damage caused.

- Penalties for misdemeanors

- Community service provision.

- Repair of the damage caused.

- Fine.

- Admonishment.

- Accessory penalties

- Prohibition to drive motorized vehicles.

The study of protective measures in Chile shows that it is a corrective and oppressive system, according to (Berrios 2011, 25), who states that juvenile justice functions in a way that is just like adult criminal justice. The most serious problems focus on provisional detention and the penalty of confinement in a closed regime.

The other Latin American countries have adopted criminal statutes for minors, including the measures that have been commented on this paper. For example, Guatemala calls it the Children and Youth Code, which establishes the age of minority between 12 and 18 years. El Salvador calls it the Law on Juvenile 
Offenders, in the Dominican Republic, the Code for the Protection of Children and Adolescents, among others.

\section{CONCLUSIONS}

Judicial measures for minors, such as: reprimands, rules of conduct, community social services, probation, half-closed detention and deprivation of liberty, are the most commonly accepted by Latin American legal systems. An analysis compared to judicial measures in other countries shows the lack of other measures such as therapeutic internment, outpatient treatment, weekend stays, living with another person, family or educational group, which would undoubtedly strengthen the catalogue of current measures.

The formal existence of legal measures for juvenile offenders will not be sufficient, but there should also be an effective budgetary allocation of resources to guarantee their execution.

\section{REFERENCES}

- Aguado, Mapelli., and Gonzáles Maria. 2002. "Basis of responsibility of minors". Comments to the Organic Law 5/2000, January 12. Regulator of Criminal Liability of Minors. Seville: Andalusian Institute of Public Administration. 65-66.

- Álvarez, Isidoro. 2007. Open environment centres and services in Andalusia and some comments on certain aspects of juvenile criminal legislation. In Juvenile Justice Yearbook. ISSN 1579-4784.

- Arangüena, Coral. 1991 General Theory of Real Precautionary Measures in Spanish Criminal Proceedings. Barcelona: Bosch

- Belinchón, Maria. 2001. Regulating law of the criminal liability of minors. Seville: El Monte Foundation

- Bellof, Mary. 1998. Juvenile criminal responsibility systems in Latin America. Bogotá: Temis/Depalma. 
- Berrios, Gonzalo. 2011. The law on the criminal responsibility of adolescents as a justice system: analysis and proposals. Criminal politics. Vol. 6(11). Art. 6.. 163191. http://www.politicacriminal.cl/Vol_06/n_11/Vol6N11A6.pdf

- Boldov, Miguel. 2002. "Main substantive aspects of the new Spanish juvenile criminal law". Science of Criminal Law in the New Century. Díez Ripollés, Jose. Romeo Casabona, et. al. Madrid: Editorial Tecnos.

- Carmona, Carmen. 2002. "Measures and Criteria for the Determination of Law 5/2000 Regulating the Criminal Responsibility of Minors, in Guarantees of the Defendant in Criminal Proceedings. Legal protection of minors". Juridical Studies Magazine, Public Prosecutor's Office, Training of specialist prosecutors for minors. N. 1. Madrid: Ministry of Justice

- Carmona, Maria. 2013. "Guidelines derived from the Convention on the Rights of the Child in Situations of Deprivation of Liberty". Juvenile Justice Yearbook.

- Cezón, Carlos. 2001. The new Organic Law regulating the Criminal Responsibility of Minors. Barcelona: Bosch

- Chocrón, Ana. 2008. Precautionary measures in juvenile criminal proceedings. In the university expert in juvenile justice.

- Collado, Enrique. 2000. Practical manual of precautionary measures (constitutional, ordinary and special processes). Adapted to the new Law on Civil Procedure and Juvenile Proceedings. Granada: Comares.

- Cuello, Joaquín. 2000. The new juvenile criminal law. Madrid: Civitas Ediciones S.L.

- Cruz, Beatriz. 2006. General education and prevention in juvenile criminal law. Barcelona: Marcial Pons.

- Instituto de Estudios del Ministerio Público, El IEMP 1995. The Institute of Studies of the Public Prosecutor's Office established in 1995 (Article 22 of Law 201 of 1995).

- Espitía, Fabio. 2003. Institutions of criminal procedural law. Bogotá: Legis.

- Forero, Elvira, NAVARRO, Rosa, VILLAVECES, Maria E. et. al. 2010. Technical Administrative Guideline for the Care of Adolescents in the System of Criminal Responsibility for Adolescents (SRPA). Bogotá: Ministry of Social Protection, Colombian Family Welfare Institute.

- García-Rostán, Gemma. 2007. The juvenile criminal process. Functions of the Public Prosecutor's Office and the Judge in the Instruction, the intermediate period and the precautionary measures. Pamplona: Aranzadi. 
- Gómez, Maria. 2001. "The Regime of Measures Applicable to Minors: Organic Laws 5/2000 y 7/2000".Juvenile Justice Yearbook.

- Hava, Esther. 2004. "The measures applicable to minors in Law 5/2000". Minors. Criminal responsibility and psychosocial care. Eds RUIZ, Luis y NAVARRO, José. Valencia: Tirant lo Blanch. ISBN 84-8442-982-2.

- Landrove, Gerardo. 2001, "Measures applicable to juvenile offenders". Criminal law, society and new technologies. Eds ZÚÑIGA Laura, MÉNDEZ Cristina, DIEGO María. Madrid: Colex.

- Organic Law. 2000. Regulator of the criminal responsibility of minors. Published in BOE N. 11 on January 13 / 2000. Spain.

- Mapelli Caffarena, Borja. 2004. "Special rules for the enforcement of measures involving deprivation of liberty". Minors. Criminal responsibility and psychosocial care. Valencia: Tirant lo Blanch.

- Martín, José. 2008. Juvenile criminal justice. Ed Martín López, María. University of Castilla-La Mancha.

- Martín, Maria. 2001. "Models of juvenile justice: analysis of comparative law". Criminal responsibility of minors. Ed Martín López, M. Teresa. Universidad de Castilla-La Mancha, Martín López.

- Muñoz, Jose. 2001. Study on measures in the Organic Law on the Criminal Responsibility of Minors. Journal of Legal Studies. Public Prosecutor's Office N. 1. Madrid: Ministry of Justice.

- Pollarolo, Fanny. 2009. Semi-closed Admission with Social Reinsertion Program. Santiago de Chile: Department of Juvenile Rights and Accountability. Online at: http://www.sename.cl/wsename/otros/20084/3-CSC-final.pdf

- Portal, José. 2005. "Present and future of personal precautionary measures in the law on criminal liability of minors". Juvenile Justice Yearbook.

- Portal, José. 2008. Personal precautionary measures in the criminal proceedings of minors. Madrid: Legal Dissemination and Current Issues S.A.

- Puente, Luz. 2006. "New reforms in juvenile criminal law: measures of internment and the protection of aggrieved parties". Juvenile Justice Yearbook.

- United Nations General Assembly. 1985. Beijing Rules, United Nations Standard Minimum Rules for the Administration of Juvenile Justice. Resolution 40/33.

- United Nations General Assembly. 1989. CDN. Convention on the Rights of the Child. Ratified in 1989 and effective from 1990. 
- Rodríguez, Juana. 2004. Some peculiarities of juvenile criminal proceedings. Annals of the Faculty of Law. N. 21:169-183. http:// publica.webs.ull.es/upload/REV\%20ANALES/212004/09\%20\%28J uana\%20Pilar\%20Rodr\%C3\%ADguez\%20P\%C3\%A9rez\%29.pdf.

- Sanz, Agata. 2007. "Precautionary measures". Comments on the Criminal Law on Minors (in accordance with the amendments introduced by LO 8/2006). Ed Gómez, M $M^{\mathrm{a}}$. $1^{\text {st }}$ edition. Madrid: Iustel.

- Tejedor, Antonia. 2001. "Psychological intervention in the field of juvenile justice". Juvenile Justice Yearbook. ISSN 1579-4784.

- Trejo, Martin. 2005. "Approximation to the dogmatic of the judicial individualization of the measure of internment". Juvenile Justice Yearbook.

- Valbuena, Esther. 2008. Precautionary measures in the prosecution of minors. Navarra: Aranzadi. $1^{\text {st }}$ edition. ISBN 9788483557389.

- Vásquez, Carlos., y SERRANO Tárraga, Maria. 2007. Juvenile criminal law. Madrid: Dykinson.

- Vizcarro, i Masià. 2001. "Execution of the measures of internment and open environment". The criminal responsibility of minors. ed MARTÍN, Maria. Cuenca: Edition at University of Castilla - La Mancha. 